\title{
Mycorrhizae Make the Difference by Paul Reed Hepperly and David Douds
}

\author{
Paul Reed Hepperly* \\ University of Puerto Rico at Mayagüez, Puerto Rico \\ *Corresponding author: Paul Reed Hepperly, University of Puerto Rico at Mayagüez, Puerto Rico \\ Submission: 制September 21, 2017; Published: 制January 29, 2018
}

\begin{abstract}
Mycorrhizal fungi cannot be cultured apart of living plant roots. Found underneath the soil, they work inconspicuously. Because they only grow on living plant roots, they are known as obligate symbionts. This signify their dependence of growing into and from the host of plant roots and divulges there largely beneficial effects on the host plants. Mycorrhizae derives from the Greek myco fungus and rhizae roots. About $80 \%$ of all land plants depend on these fungi to find and procure of water and nutrients for plant growth and development. The fungal roots or mycorrhizal associations are underground but represent a massive web of opportunity.

Mycorrhizal evolution appearance coincides with land plant development over 400 million years ago (Remey 1990). Scientists speculate mycorrhizae were needed in order to allow plants to adapt to periodically dry land surfaces. Leonardo da Vincionce remarked, "in order to be a successful farmer one must know the nature of the soil". Even today in the age of hydroponics, most of our food is grown from field on a soil medium, over $98 \%$. Researchers suggest that less than 1 of 20 soil microorganisms have ever been identified and cultured. Considering this startling statistic, soil microbiology still represents a largely unchartered vast frontier filled with promise and potential.
\end{abstract}

\section{Introduction}

While traditionally underappreciated, mycorrhizal fungiare increasingly studied and their prevalence and benefits are becoming ever more realized. You might not know still that the foremost content of microbes in soils based on their mass is mycorrhizal fungi. While a $75 \mathrm{~kg}$ man may cultivate an acre of land the mass of fungal mycorrhizae can by 20 to 40 times that human mass and labor force. For the most part the hidden fungal work force works feverishly without our knowledge and appreciation. If you said you were aware the microbial importance of mycorrhizal fungi in soil you are one of a selected students with atypical knowledge about the nature and role of these important under looked organisms which predominate in our soil. While the development of top soil is considered a slow millennial process, losses of top soil by erosion can be more rapid devastating and dramatic. Top soil erosion losses can easily overrun the natural capacity to generate fertile top soil. While erosion has been viewed as a physical process, everything in the soil is affected by the life within it. Indeed soil organic matter is the signature of life activity in the soil itself. Indeed the living ability of microbes can greatly augment physical and chemical processes without the intervention of biological forces.

Since mycorrhizae are so common and prolific, could omnipresent mycorrhizal fungi change the lose of soil equation and reverse the effects of soil deterioration?. If they can how do they do it?. The traditional underestimation of mycorrhizal importance might be partly because most scientists have little knowledge experience or appreciation for these microscopic underground denizon of the dark soil underground. Even if you are agricultural scientist, you may never have had any course on mycorrhizal fungi and their importance. Even many mycologists are not well versed on this topic Figure 1.

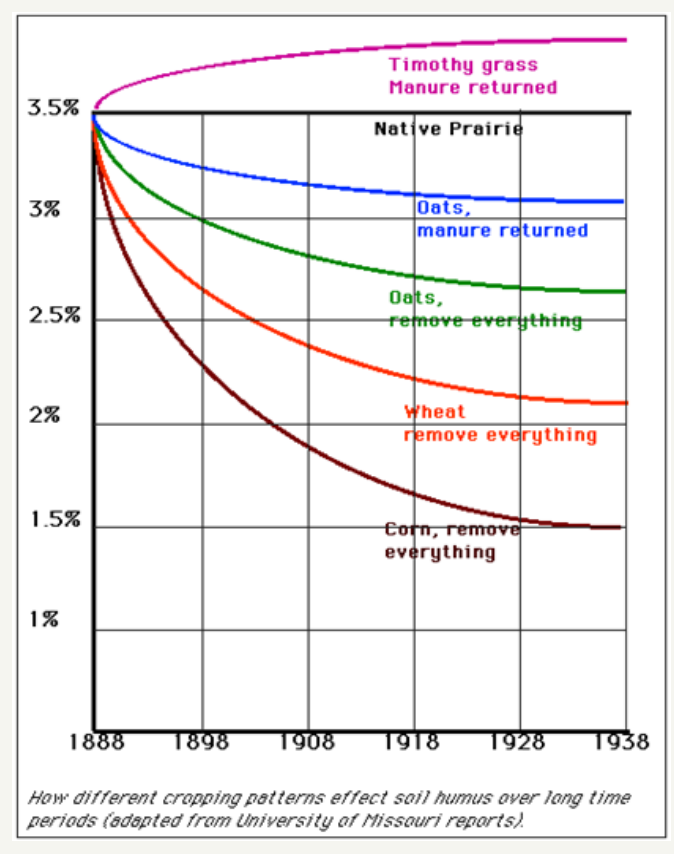

Figure 1 
Historically, there have been more prolific study of how the loss of top soil and the decay of soil organic matter can lead to a degradation of our land resources than the beneficial effects of mycorrhizae on soil. The disappearance of soil organic matter under modern cultivation practices gives a typical bath tub disappearance curve where initiation of continuous cultivation gives a rapid plummeting of the life give soil organic matter which then reaches a degraded equilibrium value less than one half of the original value.

According to George Washington, soil organic matter constitutes what he called the living heart of the soil. In 1876 the Morrow plots of the University of Illinois were started, Morrow plot rotations at University of Illinois Experimental Station has demonstrated the bath tub disappearance of soil organic matter related to modern farming techniques. These results were similar to results in Sanford plots of University of Missouri and Macgruder plots of Oklahoma State University as well as other major land grant universities. In practice the potential of loss of productivity is particularly associated with maize monoculture which dominates the modern North American land scape. These studies would suggest that modern agriculture might be attacking the living heart of our soil nationally.

During the 1930's in the United States the Great Depression coincided with massive soil erosion known as the Great Dust bowl era. In order to address this massive soil loss. The modern soil conservation methods were marshaled through Soil Conservation Service of US Department of Agriculture under President Franklin Delano Roosevelt and Agriculture Secretary Henry Wallace (Figure 2). Photo of giant dust clouds common during Great Depression during droughts in the Plains region. Franklin Delano Roosevelt President who espoused the Soil Conservation Service inauguration stated "A nation that destroys its soil destroys itself". Confucius commented that "a foot of top soil and the fact that it rained is the only thing separated our civilization from famine".

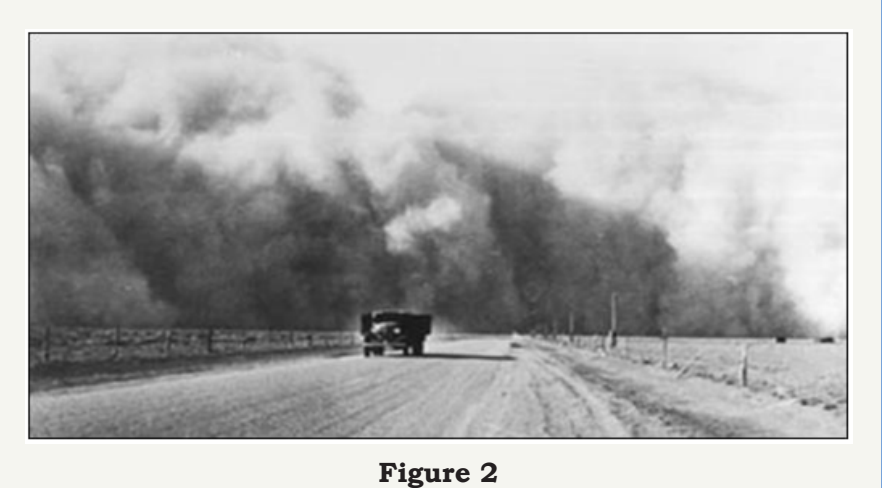

Since the end of World War 2, the high productivity of agriculture has focused on

a) Intensive use of synthetic mineral fertilizers,

b) Monocultural production methods

c) Intensive use of pesticides.

Methods that were traditionally employed for maintaining and building soils were not a prime consideration such as

i. Organic manuring

ii. Rotations

iii. Employment of forage and haying in rotations which employed mixed crop and animal systems of production.

While the Sanford plots all due to building soil organic matter through timothy and manure addition this type of farming is largely replaced by monoculture grain production systems. These systems are largely based strictly synthetic soil inputs namely synthetic pesticides and fertilizers. Synthetic pesticides, fertilizers, and tillage are the villains as they can derail the actions of mycorrhizae.

In 1981 The Rodale Institute started the Farming Systems Trial that directly compares a wholy biological input approach exemplified by the organic agricultural systems compared to a typical synthetic input approach [2]. By its design this Farming Systems Trial eschewed synthetic chemical inputs. For experimental purposes a conventional approach used a maize and soybean crop rotation with full input packages, ie fertilizers and pesticides. The biological input approach used a more extended crop rotation with cover crops and a focus on legume crops, cover cropping and organic amendment. The long term Farming Systems Trial and Compost Utilization Trials accrued over 30,000 data points showing the critical nature of soil organic matter and soil aggregation to water dynamics from their unique intact soillysimeters [3].

While the short term effects of synthetic fertilizers on crops can be rapid and spectacular the long term effects of these may be quite different. When nitrogen is applied to legumes, this will result in the atrophy of the rhizobial natural biological fixation of nitrogen. Likewise when synthetic Phosphorus is applied to the seed zones of crops it can trigger the plant not to accept the mycorrhizal fungi which mobilize soil Phosphorus from the soil to plant. Short term gains from monoculture, synthetic fertilizers, pesticides and tillage can derail long term gain from cultural practices which foster positive soil biology of whom mycorrhizal fungi along with rhizobial bacteria are chief players.

Unlike chemical input which actions rapidly the biological inputs take time to accumulate in the form soil organic matter. Only after their long term accumulation do maize yields met and exceed the chemically based input system. In the Rodale Farming System this conversion was evident by only fully competitive maize yield at and after the fourth year of the trial. After that conversion time biological input systems were superior in drought years. This was particularly evident in soybean which is more sensitive to drought than maize. Consistently superior to conventional were $25 \%$ less drought loss in maize and 50\% less drought loss soybean in the biological input systems compared to conventional control systems. These results show incremental cumulative effect of the soil improvement which Robert Rodale coined as soil regeneration which can be measured in soil organic matter content. System analysis have clearly demonstrated that not only does biological input approach produce highly competitive crop yields over time 
but the soil carbon and nitrogen values increase significantly. The Rodale Farming Systems Trial puts the soil organic matter disappearance curve on its head leading to a soil organic matter accrual curve. This is only appreciated under a long term experimental vista. The Figure 3 shows soil organic matter accrual in biological input systems green and red lines this compares to no improved of the convention compared to maize and soil rotation (grey). Compared to bathtub soil organic matter disappearance the systems shown for land grant institutions in the Mid west the Rodale biological approach puts the disappearance curve on its head breaking a myth of obligate need of high synthetic inputs. Courtesy the Rodale Institute.

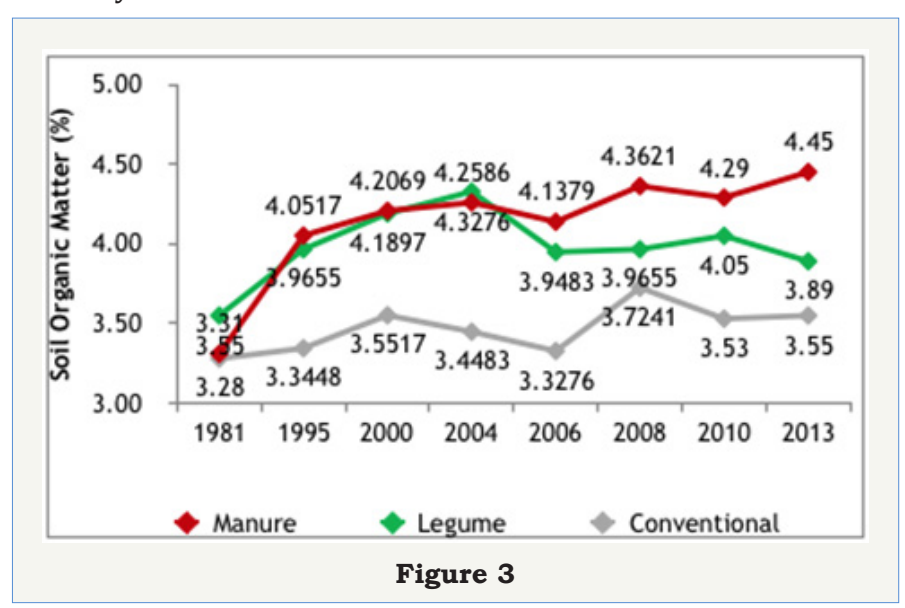

In 1996 USDA ARS Sarah Wright began proclaiming the ability to mycorrhizal fungi to capture soil carbon suggesting fully one third of the carbon in soil is related to these organisms [4,5]. Dr. Wright and her collaborators showed the profound effect of the sugary protein from mycorrhizal fungi as a key for aggregating or clumping soil. As the sticky resistant glycoprotein related substance increases the sizes and persistence of soil aggregates also increase $[6,7]$. What is the effect of persistent large aggregates but to reduce the ability of small particles to be dislodged by wind and water! Because of the long half life of glomalin, it helps mycorrhzae contribute to accumulation soil organic carbon by their resistance to decay and by the protection of soil carbon from aggregation.

In addition to ability to change soil texture, benefits of mycorrhizal aggregation include

a) Improved water percolation capture and recycling

b) Better nutrient status especially of immobile nutrients such as Phosphorus

c) Improved plant development

d) Improved soil texture

e) Less soil erosion

f) Better crop response to water stress

g) Improved tolerance to weeds, pests and pathogens.

Ecosystem analysis shows that primary plant productivity increases in relation to increase of mycorrhizal fungi measured in glomalin related soil protein content as well as mycorrhizal colonization values [8].

We reiterate that of all biological mass in the soil mycorrhizal fungi is the foremost. Studies at the Rodale Institute in collaboration with David Douds point to biological inputs including rotation, cover cropping and organic amendments can be highly stimulative to mycorrhizal diversity and activity [9]. As results from biological inputs increased it was preceded by increased prevalence and activity of mycorrhizal fungi. Reduced and no tillage can also foster better mycorrhizal activity and increased carbon sequestration values [10]. In situations where mycorrhizal activities are insufficient inoculation of mycorrhizae show positive results. Using a simple bay grass Paspalumnotatum Flugge grow out the diversity of strains and communities were effectively propagated to give ability to artificially inoculate and enhance mycorrhizal activities with positive results for crops such as potato and strawberries in multiple year trials Figure 4.

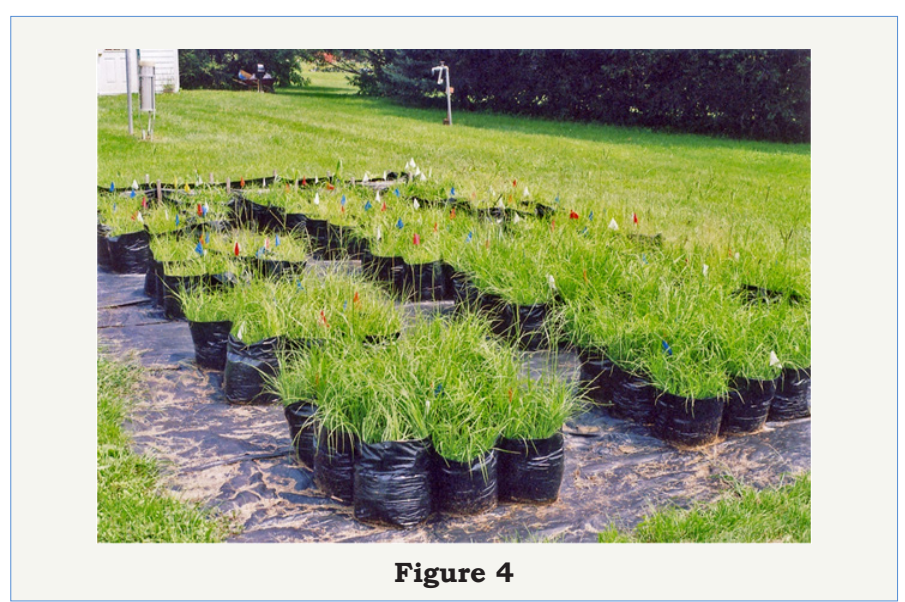

Mycorrhizal fungi increased on bay grass $P$. notatumflugge the effects of these fungi are particularly notable under periodic drought common in rain fed agriculture [11] (Photo courtesy David Douds). Increasingly the degradation of the marine resources at the mouth of major rivers is found a consequence of our monoculture cropping system and the proliferation of concentrated animal farming operations. USGS Reports suggest about $60 \%$ of the excess nitrogen in the Chesapeake Bay is from synthetic fertilization of maize and another one third is due to use of raw manures without appropriate application methods. Currently the summer dead zone at the mouth of Mississippii is greater in area than the state of New Jersey. This eutrophication is largely the consequence of loss soil and fertilizers to grow the maize crop nationally.

As legumes and cover crop build soil nitrogen the ability of farming systems to counteract these issues is clearly demonstrated in the Rodale Farming Systems Trial. Despite the great potential of we see in mycorrhizal fungi and organic amendments for their symbiotic and synergistic effects, we see slow appreciation and adoption by the agricultural community. Some scientists express a valid concern about the exact nature chemically of glomalin related soil protein citing need for better knowledge it mode of action though we concur with need for additional information we also see 
its demonstrated potential in critical issues which are pressing on our future [12].

In a warming world, we need to consider increasing soil organic matter resources. Because soil organic matter is critical to water percolation, retention and provision it holds the promise of mitigating the warming consequences of more periodic drought losses. In addition to mitigating climate change consequences it can work to reduce its source elevated atmospheric greenhouse gases. In addition, agriculture issues related to water quality and global greenhouse gas issues are addressed by putting the soil organic matter curve on its head. All in all one of the biggest potentials to counteract these issues may well be grounded in a sticky fungus we cannot yet grow aseptically in our laboratories.

Our work suggests in the roots of our crops, combined with their fungal extensions, plus the way they proliferates into our soil are critical to keeping our soil resources from being washed and blown away and have curve changing capacity which will allow a more productive agriculture future while simultaneously reducing the need for inputs which have known side effects on our soil and its biological capacity. In this regard the pioneering commercial work of Myco Applications is particularly important for its generation of extensive robust farmer databases on benefits on many crops. In addition in greenhouse studies inoculated tall fescue allowed a doubling of soil carbon in a single season of growth [13].

\section{References}

1. Amaranthus M (2008) Soil life and carbon. Acres 38(3): 5.
2. Comis D (1997) Glomalin Soils Superglue.Agriculture Research. USDA Research Service p. 23.

3. Comis D (2002) Glomalin, Hiding Place for a Third of the World's Stored Soil Cargon. Agriculture Research p. 4-7.

4. Douds DD, Nagahashi G, Hepperly PR (2010) On farm production of inoculum of indigenous arbuscular mycorrhizal fungi and assessment of diluents of compost for inoculum production. Bioresour Technol 101(7): 2326-2330.

5. Galvez L, Wagoner P, Galvez L, Douds DD (2001) Effect of tillage and farming systems on VAM and nutrient uptake. Plant and Soil 228: 299308.

6. Gillespie AW (2011) Glomalin related soil protein contains non mycorrhizal related heat stable proteins, lipids, and humic materials. Soil Biol \& Biochem 43(4): 766-777.

7. Hepperly P (2005) Water Agriculture and you.

8. Puget P, Lal R (2005) Soil organic carbon and nitrogen in a Mollisol in central Ohio as affected by tillage and land use. Soil and Tillage Research 80(1): 201-213.

9. Remy W, Taylor TN, Hass H, Kerp H (1994) Four hundred million year old vesicular arbscularmycorrhizae. Prod Natl Acad Sci 91(25): 11841011843.

10. Rillig MC (2007) Arbuscularmycorrhizae, glomalin, and soil aggregation. Canadian J Soil Sci 84(4): 355-363.

11. Rillig M, Eldor AP, Philip WR, Sherri M (2009) Glomalin, an arbuscularmycorrhizal fungal soil protein responds to land use change. Plant and Soil 253(2): 293-299.

12. Rodale Institute (2011) 30 Year Report Farming Systems Trial.

13. Treseder K, Turner K (2007) Glomalin in Ecosystems. Soil Sci Amer J 71(4): 1257-1266. 